\title{
FLT3 Length Mutations as Marker for Follow-Up Studies in Acute Myeloid Leukaemia
}

\author{
Susanne Schnittger Claudia Schoch Wolfgang Kern Wolfgang Hiddemann \\ Torsten Haferlach
}

Laboratory for Leukaemia Diagnostics, Department of Internal Medicine III, Ludwig Maximilians University of

Munich, University Hospital Grosshadern, Munich, Germany

\section{Key Words}

FLT3-LM • Minimal residual disease · AML · FLT3-ITD .

Follow-up studies

\begin{abstract}
Length mutations within the FLT3 gene (FLT3-LM) can be found in $23 \%$ of acute myeloid leukaemia (AML) and thus are the most frequent mutations in AML. FLT3-LM are highly correlated with AML with normal karyotype and other cytogenetic aberrations of the prognostically intermediate group. This group is supposed to be a mixed group of AML with differences in the underlying pathogenesis. For more individualized treatment options it would be helpful to better characterize this large AML group not only by molecular mutations but also use these markers for the definition of minimal residual disease (MRD). However, so far the cytogenetically intermediate AML has been lacking suitable markers for PCRbased MRD detection like the fusion genes in the prognostically favourable subgroups. The suitability of the FLT3-LM as a target for PCR-based MRD was discussed controversially as it seemed to be a rather unstable
\end{abstract}

\section{KARGER}

Fax +41613061234

E-Mail karger@karger.ch

www.karger.com
(C) 2004 S. Karger AG, Basel

0001-5792/04/1122-0068\$21.00/0

Accessible online at:

www. karger.com/aha marker. Thus, we aimed at the evaluation of FLT3-LM as a marker for residual disease in a large cohort of AML. Paired samples of 97 patients with AML at diagnosis and at relapse were analyzed. It could be shown that in only four cases a loss of the length mutation was detected. This is in the range of other well-characterized AML relapsing with a different geno- and/or phenotype. In contrast, a change in the ratio of the mutated allele in comparison to the wild-type allele was frequently observed. In detail, the FLT3-LM showed a tendency to accumulate during disease progression and was found more frequently at relapse than at diagnosis. In addition, 45 patients were analyzed at different time points during and after therapy. Using conventional PCR it clearly could be shown that for most of the patients positive at presentation FLT3-LM is a reliable PCR marker for monitoring treatment response. Even an early detection of relapse was possible in some cases.

Copyright $@ 2004$ S. Karger AG, Basel
Dr. rer. nat. Susanne Schnittger, Laboratory for Leukaemia Diagnostics Department of Internal Medicine III, University Hospital Grosshadern Ludwig Maximilians University, Marchioninistrasse 15

DE-81377 München (Germany), Tel. +49 897095 4970, Fax +49 8970954971

E-Mail susanne.schnittger@med3.med.uni-muenchen.de 


\section{Introduction}

FLT3 is a member of fms-like receptor tyrosine kinases and is expressed in early haematopoietic stem cells $[1,2]$. The gene coding for this receptor is targeted by mutations in the juxtamembrane domain in $20-23 \%$ of all unselected acute myeloid leukaemias (AML) [3-8]. In addition, point mutations in the activation domain have been described in an additional 6-7\% of AML [9-11]. Thus, FLT3 is the gene most commonly targeted by mutations in AML. The mutations in exon 14 and/or exon 15, the part of the gene that is coding for the juxtamembrane domain, have been described to be internal tandem duplications (ITD) resulting in the term FLT3-ITD. However, as we have found that not all of these mutations are simple ITDs but about $30 \%$ have insertions of extranucleotides between the duplicated stretches and some cases are even more complicated, we will refer to this mutations as FLT3 length mutations (FLT3-LM) [8]. The elongation of the juxtamembrane domain results in a conformation change that leads to autoactivation of the receptor through a constitutive phosphorylation [12] and can induce IL-3-independent growth in model systems [13, 14]. The FLT3-LM has been shown to be strongly correlated with AML and myelodysplastic syndromes of the RAEB and RAEBt subtypes [8, 15]. In many different study groups the FLT3-LM has been shown to be strongly correlated with the prognostically intermediate karyotype group. This large group of AML is supposed to be a pool of insufficiently characterized AML with different molecular mutations. Now it is becoming clear that the FLT3LM defines a prognostically worse subset within this group $[3,5-8,16,17]$. Today the karyotype of the leukemic cells is considered the most important parameter indicating the prognosis in patients with AML $[18,19]$. Although further pretherapeutically defined prognostic parameters have been identified such as age of the patient and AML occurring as a secondary disease the prognosis of patients within the respective subgroups defined by these parameters is still heterogeneous. As a consequence, the implementation of therapy-dependent parameters into stratification systems has been approached. Along this line, the degree of reduction of the leukemic cell mass following the first course of induction therapy as well as the time to achieve complete remission have been demonstrated to independently impact the prognosis [20-22]. These studies thus have proved the concept of prognostication based on therapy-dependent factors.

The most prominent therapy-related factor is the level of minimal residual disease (MRD). Beside the conven- tional control of therapy response by cytomorphology, assessment of MRD by flow cytometry is of growing importance [23]. However, polymerase chain reaction (PCR)-based methods are still the most sensitive ones for the detection of residual leukaemic cells. The application of PCR to quantify MRD so far was based on the presence of fusion genes or their respective fusion transcripts, which occur exclusively in the respective subentities of AML but not in normal bone marrow. In patients with AML the detection of MRD by quantitative PCR has been shown to be feasible and prognostically relevant [2432]. However, in AML with normal karyotype or other prognostically intermediate aberrations like trisomies 8 or 11 and del(9q) PCR was not applicable due to the lack of a target suitable for PCR. The portion of cases assessable may now be extended by the inclusion of cases with FLT3-LM.

To analyze whether FLT3-LM is a valuable marker for follow-up controls two different analyses were performed: (1) the stability was assessed by paired analysis of samples from diagnosis and relapse and (2) FLT3 status from samples during and after therapy was compared to the status of remission, fluorescence in situ hybridization (FISH) and cytogenetics.

\section{Patients, Materials and Methods}

\section{Patient Samples}

Bone marrow or peripheral blood samples were sent by overnight service to our lab. All were diagnosed as having AML according to standard French-American-British (FAB) criteria [33-38] and were referred between July 1997 and December 2002 for cytomorphological, cytogenetic, molecular genetic and multiparameter flow cytometry analysis.

\section{Cytogenetic and FISH Analysis}

Cytogenetic G-banding analysis was performed with standard methods [39]. The definition of a cytogenetic clone and descriptions of karyotypes followed the International System for Human Cytogenetic Nomenclature [40].

For FISH the commercially available probes CEP\#8SG, LSID7S486/CEP7, LSIPMLRARA, LSICBFB, and LSIAML1/ETO were used according to the manufacturer's instructions (Vysis, Bergisch Gladbach, Germany).

\section{Sample Preparation}

Mononucleated bone marrow cells were obtained by Ficoll-Hypaque density gradient centrifugation. Total RNA was extracted from $10^{7}$ cells with RNeasy (Qiagen, Hilden, Germany) (1997-2000) or mRNA with the MagnaPureLC mRNA Kit I (Roche Diagnostics, Mannheim, Germany) (since January 2001). The cDNA synthesis of 1-2 $\mu \mathrm{g}$ total RNA or mRNA from an equivalent of $10^{7}$ cells was performed using $300 \mathrm{U}$ Superscript II (GibcoBRL/Invitrogen, Karlsruhe, Germany) and random hexamer primers (Pharmacia, Freiburg, 
Germany). DNA was extracted using a simple salting-out procedure [41].

\section{PCR at Diagnosis}

PCR and semiquantitative estimation of the FLT3-LM status was performed as has been described [8]. Strict precautions were taken to prevent contamination. Water instead of cDNA was included as a blank sample in each experiment. Amplification products were analyzed on $2 \%$ agarose gels stained with ethidium bromide.

\section{Sequencing}

For direct sequencing of the length mutations the amplified fragments were cut from the agarose gels and isolated with Quiaex II (Qiagen) following the manufacturer's instructions. Approximately $100 \mathrm{ng}$ of purified PCR products were directly sequenced with 3.3 pmol of primers as described above with the Big Dye Terminator Cycle Sequencing Kit (Applied Biosystems, Weiterstadt, Germany). After initial denaturation at $95^{\circ} \mathrm{C}$ for $5 \mathrm{~min}, 25$ cycles at $94^{\circ} \mathrm{C}$ for $15 \mathrm{~s}$ and $60^{\circ} \mathrm{C}$ for $4 \mathrm{~min}$ were performed. Cases with a relatively small length of the mutations or those with status 1 or 5 mutations were subcloned using the TOPO II cloning system (Invitrogen, Karlsruhe, Germany) prior to sequence analysis. Sequence detection was performed on an ABI 310 sequence detection system (Applied Biosystems).

Efficiencies, Reproducibility and Sensitivities of the PCR Assays

The sensitivity of the PCR assays was assessed by performing limited dilution series of DNA and cDNA of diagnostic patient samples with a different status of FLT3-LM into cDNA of samples without FLT3-LM.

\section{Results}

\section{Frequency of FLT3-LM at Presentation and in Relapse}

In total 2,338 samples were analyzed, 2,135 were from newly diagnosed AML and 203 from relapsed AML. FLT3-LM were found in $461(21.6 \%)$ of the diagnostic samples at first diagnosis and in $62(30.5 \%)$ of the relapses. Thus the frequency is higher in relapsed AML (table 1) $(p=0.005)$.

\section{Semiquantitative Analysis of the Mutations}

Analysis of the amplification fragments on agarose gels revealed that the band representing the mutation was not always of the same intensity as the wild-type allele. Thus, we divided the FLT3-LM into five categories: (1) mutant fragment less intense than wild-type band (status 1), (2) mutant fragment with the same intensity as wild-type band (status 2), (3) mutant fragment more intense than wild-type band (status 3), (4) only mutant fragment and loss of wild-type band (status 4), and (5) presence of more than one mutant fragment (status 5) (fig. 1). Type 1 has to be interpreted as subclone in an otherwise FLT3-LM-neg-
Table 1. FLT3-LM status according to a semiquantitative estimation in a cohort of 2,135 AML patients at diagnosis and 203 at relapse

\begin{tabular}{lll}
\hline $\begin{array}{l}\text { Mutation } \\
\text { status }\end{array}$ & $\begin{array}{l}\text { Diagnoses } \\
(461 / 2,135 ; 21.6 \%), \%\end{array}$ & $\begin{array}{l}\text { Relapse } \\
(62 / 203 ; 30.5 \%), \%\end{array}$ \\
\hline 1 & 10 & - \\
2 & 60 & 16 \\
3 & 11 & 32 \\
4 & 6 & 52 \\
5 & 13 & - \\
\hline
\end{tabular}

ative population, type 2 as an equal amount of wild-type and mutated allele, type 3 as loss of the wild type in a subclone, and type 4 as complete loss of the wild type. In type 5 there were two different FLT3-LM in different clones.

At diagnosis $70 \%$ of the patients with FLT3-LM have status 1 and 2 mutations, whereas a loss or partial loss of the wild-type allele was found in only $17 \%$. In contrast, in relapses status 1 and 5 was never detected and status 2 in only $16 \%$. Most of the relapsed FLT3-LM-positive cases had a partial $(32 \%)$ or complete $(52 \%)$ loss of the WTFLT3.

\section{Use of DNA and cDNA for PCR Diagnostics}

The PCR screening for FLT3-LM was done at the genomic and cDNA level in parallel for most of the cases. For some cases with limited material the analysis was restricted to the cDNA level. No major differences concerning the intensities of the mutated allele in comparison to the wild-type allele were observed, suggesting that there were no major expression differences between wild-type and mutated alleles.

At diagnosis it was possible to detect an FLT3 expression in every sample. In contrast, in follow-up samples of patients in complete clinical remission, it was not always possible to obtain an amplification product of FLT3 by PCR. This is in accordance with previous studies that have shown FLT3 expression on early haematological and leukaemic cells but not on differentiated haematological cells [2]. Thus for follow-up controls DNA is highly recommended as diagnostic material.

\section{Paired Samples from Diagnosis and Relapse}

In total the FLT3 status was assessed in 97 paired samples at diagnosis and at relapse (table 2). Fifty-one patients were negative at both time points. Thirty-eight 
Fig. 1. Assessment of the FLT3-LM status according to mutation/wild-type relation.

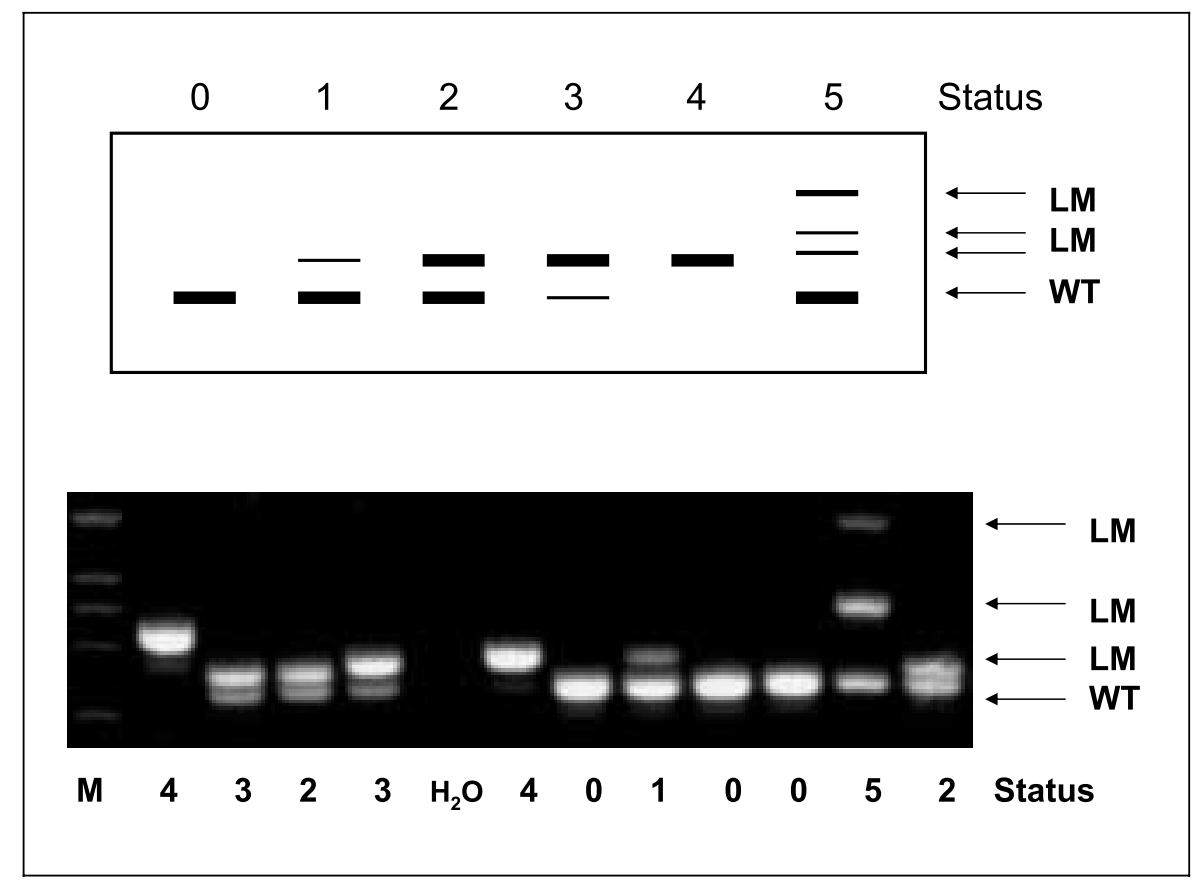

Table 2. FLT3-LM in paired presentation and relapse samples: present study and review of the literature

\begin{tabular}{lccccc}
\hline & \multirow{2}{*}{ Patients } & \multicolumn{5}{c}{ FLT3 status at presentation/relapse } \\
\cline { 3 - 6 } & & $-l-$ & $-l+$ & $+/-$ & $+/+$ \\
\hline Nakano et al. [48] & 28 & 16 & 6 & 1 & $5^{*}$ \\
Kottaridis et al. [16] & 44 & 20 & 4 & 5 & $15^{*}$ \\
Hovland et al. [42] & 2 & - & 1 & - & 1 \\
Shih et al. [44] & 108 & 83 & 8 & 1 & $16^{*}$ \\
Present study & 97 & 51 & 4 & 4 & 38 \\
\hline Total & 278 & $170(61.2 \%)$ & $23(8.3 \%)$ & $11(4 \%)$ & $75(27 \%)$ \\
\hline
\end{tabular}

cases were positive for an FLT3-LM at both time points. All 3 cases with a second relapse retained the FLT3-LM at that time point. A gain of an FLT3-LM was found in 4 cases. A loss of the mutation was detected in only 4 cases (IDs 2, 41, 42, 43), three of whom had only a status 1 mutation at presentation (table 3 ), meaning that at diagnosis only a subclone of all leukemic cells had the mutation. Of the 4 cases with a gain of the FLT3 mutation, in two (IDs 44 and 47) also a change of the FAB from M4 to M2 and M6 to M1, a change of the immunophenotype and in case 47 also a different karyotype were observed raising the question of whether these two might be secondary AML rather than relapsed AML. In addition, in case 46 the same FAB but a complete change of the karyotype was observed.

Focussing on the FLT3 status (relation of the mutated to the WT-FLT3) in more detail (table 4 and 5) we found stability of the status in 12 cases $(24.5 \%)$; however, a progression from lower to higher status was detected in 30 cases $(63 \%)$ and a regression to lower status or loss of the FLT3-LM in only 6 cases $(12.2 \%)$. Thus the overall maintenance of an FLT3-LM in relapse was relatively stable with $(45 / 49 ; 91.8 \%)$. However the mutation had a tendency to accumulate during progression of leukaemia. 
Table 3. Paired samples of patients with FLT3-LM at diagnosis and/or relapse $(n=47)$

\begin{tabular}{|c|c|c|c|c|c|c|c|}
\hline ID & FAB & $\begin{array}{l}\text { FLT3-LM } \\
\text { status }\end{array}$ & Karyotype & ID & FAB & $\begin{array}{l}\text { FLT3-LM } \\
\text { status }\end{array}$ & Karyotype \\
\hline $1 \mathrm{PD}$ & M0 & 3 & $46, X X[24]$ & $27 \mathrm{PD}$ & M0 & 2 & $48, \mathrm{XX},+8,+22[4] / 46, \mathrm{XX}[20]$ \\
\hline $1 \mathrm{Rel}$ & M0 & 3 & $46, \mathrm{XX}[5]$ & & (Chlorom) & & \\
\hline $2 \mathrm{PD}$ & M1 & 2 & $46, \mathrm{XX}[25]$ & 27 Rel & M0 & 3 & $50, \mathrm{XX},+\mathrm{X},+8,+10,+13[3]$ \\
\hline 2 Rel & M1 & - & $46, \mathrm{XX}$ & $28 \mathrm{PD}$ & M2 & 2 & $47, X X, \operatorname{del}(5)(q 15 q 33)+11[20]$ \\
\hline $3 \mathrm{PD}$ & M1 & 2 & $46, \mathrm{XX}[25]$ & $28 \mathrm{Rel}$ & M2 & 3 & $47, \mathrm{XX}, \operatorname{del}(5)(\mathrm{q} 15 \mathrm{q} 33)+11[9] /$ \\
\hline 3 Rel & M1 & 3 & $46, \mathrm{XX}[8]$ & & & & 47,idem,del(17)(q23)[9]/ \\
\hline $4 \mathrm{PD}$ & M1 & 2 & $46, \mathrm{XX}[25]$ & & & & 47,idem,add(7)(q3?4)[2] \\
\hline \multirow[t]{2}{*}{4 Rel } & M1 & 3 & $46, X, \operatorname{del}(X)(\mathrm{q} 11), \mathrm{t}(7 ; 18)(\mathrm{q} 22 ; \mathrm{p} 11.2)[8] /$ & $29 \mathrm{PD}$ & M4 & 2 & $46, X X, \operatorname{inv}(3)(q 21 q 26)[17] / 46, X X[8]$ \\
\hline & & & $46, \mathrm{XX}[7]$ & 29 Rel & M4 & 3 & $46, X X, \operatorname{inv}(3)(q 21 q 26)[7] / 46, X X[13]$ \\
\hline $5 \mathrm{PD}$ & M1 & 4 & $48, \mathrm{XY},+8,+10[10]$ & $30 \mathrm{PD}$ & tM4 & 5 & $46, X, i(X)(q 10)[4]$ \\
\hline 5 Rel & M1 & 2 & $46, \mathrm{XY}[25]$ & & & & $46, X X[19]$ \\
\hline $6 \mathrm{PD}$ & M1 & 4 & $46, X Y[20]$ & 30 Rel & M1 & 2 & $46, X X[20]$ \\
\hline 6 Rel & M1 & 4 & n.d. & $31 \mathrm{PD}$ & M5a & 1 & $46, X Y, \operatorname{del}(11)(q 13 q 21)$ or \\
\hline $7 \mathrm{PD}$ & $\mathrm{M} 1 / \mathrm{M} 2$ & 2 & $46, X Y[6]$ & & & & $\operatorname{del}(11)(q 21 \mathrm{q} 23)[6] / 47$, idem,$+8[13] /$ \\
\hline 7 Rel & $?$ & 4 & n.d. & & & & $46, \mathrm{XY}[3]$ \\
\hline $8 \mathrm{PD}$ & M2/M4 & 1 & $46, \mathrm{XX}[12]$ & 31 Rel & M5a & 2 & $46, X Y, \operatorname{del}(11)(q 13 q 21)$ or \\
\hline 8 Rel & $\mathrm{M} 2$ & 3 & n.d. & & & & $\operatorname{del}(11)(\mathrm{q} 21 \mathrm{q} 23)[1] / 47, \mathrm{idem},+8[19]$ \\
\hline $9 \mathrm{PD}$ & $\mathrm{M} 2$ & 4 & $46, \mathrm{XX}[25]$ & $32 \mathrm{PD}$ & M5b & 2 & $47, \mathrm{XY},+8[16] / 46, \mathrm{XY}[4]$ \\
\hline 9 Rel & M2 & 4 & $46, \mathrm{XX}[6]$ & 32 Rel & M5b & 2 & $47, \mathrm{XY},+8[15]$ \\
\hline $10 \mathrm{PD}$ & M2 & 1 & $46, \mathrm{XY}[25]$ & & & & $47, \mathrm{XY}, \mathrm{t}(1 ; 18)(\mathrm{p} 22 ; \mathrm{q} 23),+8, \operatorname{del}(11)$ \\
\hline 10 Rel & M2 & 4 & $46, X Y[21]$ & & & & $(\mathrm{p} 11.2 \mathrm{p} 15)[5]$ \\
\hline $11 \mathrm{PD}$ & M2 & 2 & $46, X Y[22]$ & $33 \mathrm{PD}$ & M1 & 1 & $46, \mathrm{XX}[25]$ \\
\hline $11 \mathrm{Rel}$ & M2. & 3 & $46, \mathrm{XY}[25]$ & 33 Rel & M1 & 3 & $46, \mathrm{XX}[15]$ \\
\hline $12 \mathrm{PD}$ & M2 & 2 & $46, X Y[25]$ & $34 \mathrm{PD}$ & M1 & 1 & $46, \mathrm{XX}[22]$ \\
\hline 12 Rel & $\mathrm{M} 2$ & 4 & $49, \mathrm{XY},+8,+13,+19[20]$ & 34 Rel & M1 & 4 & $46, X X[25]$ \\
\hline $13 \mathrm{PD}$ & M2 & 2 & $46, \mathrm{XX}[24]$ & $35 \mathrm{PD}$ & M2 & 2 & $46, X Y, \operatorname{der}(7) \mathrm{t}(1 ; 7)(\mathrm{q} 31 ; \mathrm{q} 32)[8] / 46, \mathrm{XY}[8]$ \\
\hline 131. Rel & M2 & 2 & $\begin{array}{l}46, \mathrm{XX}, \mathrm{t}(1 ; 19 ; 3)(\mathrm{p} 32 ; \mathrm{q} 13 ? ; \mathrm{p} 21)[25] / \\
46, \mathrm{XX}[2]\end{array}$ & $35 \mathrm{Rel}$ & M2 & 4 & $\begin{array}{l}46, X Y, t(3 ; 6)(\mathrm{q} 21 ; \mathrm{p} 12), \operatorname{der}(7) \mathrm{t}(1 ; 7) \\
(\mathrm{q} 31 ; \mathrm{q} 32), \operatorname{der}(10) \mathrm{t}(8 ; 10)(\mathrm{q} 22 ; \mathrm{q} 26), \mathrm{t}(12 ; 15)\end{array}$ \\
\hline \multirow[t]{2}{*}{ 132. Rel } & $\mathrm{M} 2$ & 2 & $46, \mathrm{XX}, \mathrm{t}(1 ; 19 ; 3)(\mathrm{p} 32 ; \mathrm{q} 13 ? ; \mathrm{p} 21)[14] /$ & & & & $(\mathrm{q} 13 ; \mathrm{q} 22)[13] / 46, \mathrm{XY}[2]$ \\
\hline & & & $46, \mathrm{XX}[1]$ & $36 \mathrm{PD}$ & M1 & 2 & $46, \mathrm{XX}[21]$ \\
\hline $14 \mathrm{PD}$ & M4 & 5 & $46, X X[25]$ & 36 Rel & M2 & 4 & $46, X X[20]$ \\
\hline 14 Rel & $?$ & 5 & $46, \mathrm{XX}[25]$ & $37 \mathrm{PD}$ & M5b & 2 & $46, \mathrm{XX}[25]$ \\
\hline $15 \mathrm{PD}$ & M4 & 2 & $46, X X[25]$ & 37 Rel & M5b & 2 & $46, X X[25]$ \\
\hline 15 Rel & M4 & 3 & $46, \mathrm{XX}[25]$ & $38 \mathrm{PD}$ & $\mathrm{M} 3 \mathrm{v}$ & 1 & $46, X Y, t(15 ; 17)(q 22 ; q 12)[3] 46, X Y$, \\
\hline $16 \mathrm{PD}$ & M4 & 3 & $46, \mathrm{XX}[25]$ & & & & $\operatorname{der}(15) \mathrm{t}(15 ; 17)(\mathrm{q} 22 ; \mathrm{q} 12), \operatorname{ider}(17)(\mathrm{q} 10)$ \\
\hline 16 Rel & M4 & 3 & $46, \mathrm{XX}[25]$ & & & & $\mathrm{t}(15 ; 17)(\mathrm{q} 22 ; \mathrm{q} 12)[17]$ \\
\hline $17 \mathrm{PD}$ & M4 & 2 & $46, \mathrm{XX}[25]$ & 38 Rel & $\mathrm{M} 3 \mathrm{v}$ & 3 & $46, X Y, t(15 ; 17)(\mathrm{q} 22 ; \mathrm{q} 21)[18] / 46, \mathrm{XY}[2]$ \\
\hline 17 Rel & M4 & 3 & $46, \mathrm{XX}[15]$ & $39 \mathrm{PD}$ & M5a & 1 & $46, \mathrm{XX}[25]$ \\
\hline $18 \mathrm{PD}$ & M4/M5 & 2 & $46, \mathrm{XY}[25]$ & 39 Rel & M5a & 4 & $46, \mathrm{XX}[25]$ \\
\hline \multirow[t]{2}{*}{$18 \mathrm{Rel}$} & M4/M5 & 2 & $48, \mathrm{XY}, \mathrm{t}(2 ; 3)(\mathrm{q} 31 ; \mathrm{p} 21),+8,+8, \mathrm{t}(10 ; 17)$ & $40 \mathrm{PD}$ & M1 & 1 & $46, \mathrm{XY}[21]$ \\
\hline & & & $(\mathrm{q} 22 ; \mathrm{q} 22), \operatorname{del}(13)(\mathrm{q} 14 \mathrm{q} 31)[13] / 46, \mathrm{XY}[12]$ & 40 Rel & M1 & 4 & $46, X Y[18]$ \\
\hline $19 \mathrm{PD}$ & M4 & 3 & $46, \mathrm{XX}[25]$ & $41 \mathrm{PD}$ & M2 & 1 & $46, X X, t(8 ; 21)(\mathrm{q} 22 ; \mathrm{q} 22)[19] / 46, \mathrm{XX}[1]$ \\
\hline 19 Rel & M4Rez & 4 & $46, \mathrm{XX}[25]$ & 41 Rel & M2 & 0 & $46, \mathrm{XX}, \mathrm{t}(8 ; 21)(\mathrm{q} 22 ; \mathrm{q} 22)[11] / 46, \mathrm{XX}[4]$ \\
\hline $20 \mathrm{PD}$ & M5b & 3 & $46, \mathrm{XX}[20]$ & $42 \mathrm{PD}$ & SAML & 1 & $47, \mathrm{XY},+8[15]$ \\
\hline 201. Rel & M5b & 4 & $46, X X[20]$ & 42 Rel & sAML & 0 & $47, \mathrm{XY},+8[4] / 46, \mathrm{XY}[16]$ \\
\hline 20 2. Rel & M5b & 4 & $46, \mathrm{XX}[20]$ & $43 \mathrm{PD}$ & M4eo & 1 & $46, X Y, \operatorname{inv}(16)(\mathrm{p} 13 \mathrm{q} 22)[2] /$ \\
\hline $21 \mathrm{PD}$ & M5b & 3 & $46, \mathrm{XX}[25]$ & & & & $47, \mathrm{XY},+8, \operatorname{inv}(16)(\mathrm{p} 13 \mathrm{q} 22)[1] 49, \mathrm{XY}, \operatorname{del}(1)$ \\
\hline 21 Rel & M5bRez & 4 & $46, \mathrm{XX}[25]$ & & & & $(\mathrm{q} 21),+8,+13, \operatorname{inv}(16)(\mathrm{p} 13 \mathrm{q} 22),+21[4]$ \\
\hline $22 \mathrm{PD}$ & M5b & 1 & $46, \mathrm{XX}[25]$ & 43 Rel & M4eo & 0 & $46, X Y, \operatorname{inv}(16)(p 13 q 22)$ \\
\hline 22 Rel & M1 & 4 & $46, \mathrm{XX}[25]$ & & & & {$[1] \backslash \mathrm{n} 47, \mathrm{XY},+8, \operatorname{inv}(16)(\mathrm{p} 13 \mathrm{q} 22)$} \\
\hline $23 \mathrm{PD}$ & AML & 2 & $46, X Y[15]$ & $44 \mathrm{PD}$ & M4 & 0 & $46, \mathrm{XX}[25]$ \\
\hline 23 1. Rel & AML & 2 & $46, X Y, t(10 ; 12)(q 22 ; p 13)[6] / 46, X Y[6]$ & 44 Rel & M2 & 3 & $46, \mathrm{XX}[20]$ \\
\hline 232. Rel & AML & 2 & $46, \mathrm{XY}, \mathrm{t}(10 ; 12)(\mathrm{q} 22 ; \mathrm{p} 13)[14] / 46, \mathrm{XY}[1]$ & $45 \mathrm{PD}$ & M1 & 0 & $46, \mathrm{XX}[26]$ \\
\hline $24 \mathrm{PD}$ & M2 & 2 & $46, \mathrm{XY}, \mathrm{t}(8 ; 21)(\mathrm{q} 22 ; \mathrm{q} 22)[25]$ & 45 Rel & M1 & 1 & $46, \mathrm{XX}[20]$ \\
\hline \multirow[t]{3}{*}{24 Rel } & M2 & 2 & $46, \mathrm{XY}, \mathrm{t}(1 ; 5)(\mathrm{q} 21 ; \mathrm{q} 33), \mathrm{t}(8 ; 21)(\mathrm{q} 22 ; \mathrm{q} 22)[6] /$ & $46 \mathrm{PD}$ & M1 & 0 & 46,XY,del(7)(q21)[5]/46,XY [13] \\
\hline & & & $46, \mathrm{XY}, \mathrm{t}(1 ; 5)(\mathrm{q} 21 ; \mathrm{q} 33), \mathrm{t}(8 ; 21)(\mathrm{q} 22 ; \mathrm{q} 22)$ & 46 Rel & M1 & 2 & $47, \mathrm{XY},+13[2] / 47, \mathrm{XY},+15[2] / 46, \mathrm{XY}[7]$ \\
\hline & & & $\operatorname{del}(11)(\mathrm{p} 13)[4]$ & $47 \mathrm{PD}$ & M6 & 0 & $47, \mathrm{XY},+8[12] / 46, \mathrm{XY}[8]$ \\
\hline $25 \mathrm{PD}$ & $\mathrm{M} 0 / \mathrm{M} 1$ & 2 & $46, X Y, \operatorname{der}(5) \mathrm{t}(5 ; 11)(\mathrm{q} 22 ; ?)[9] / 46, \mathrm{XY}[11]$ & 47 Rel & M1 & 4 & $46, X Y, t(1 ; 17)(\mathrm{q} 21 ; \mathrm{q} 23), \operatorname{inv}(6)(\mathrm{p} 21 \mathrm{q} 27)$, \\
\hline $25 \mathrm{Rel}$ & M0 & 3 & $46, X Y[20]$ & & & & $\mathrm{t}(9 ; 13)(\mathrm{q} 21 ; \mathrm{q} 14)[5] / 46, \mathrm{XY}[16]$ \\
\hline $26 \mathrm{PD}$ & M0 & 2 & $46, X Y, t(11 ; 19)(q 13 ; p 13)[17] / 46, X Y[3]$ & & & & \\
\hline 26 Rel & M0 & 2 & $46, X Y, t(11 ; 19)(q 13 ; p 13)[9] / 46, X Y[1]$ & & imonx & 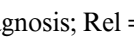 & $=$ relapse n. d. $=$ not done \\
\hline
\end{tabular}


Table 4. FLT3-LM status in paired samples at presentation and relapse $(n=49)$

\begin{tabular}{|c|c|c|c|c|c|c|c|c|c|c|c|c|c|c|c|c|c|c|}
\hline \multicolumn{19}{|c|}{ FLT3 status at diagnosis } \\
\hline 1 & 2 & 3 & 4 & 5 & 0 & 0 & 0 & 0 & 1 & 1 & 1 & 2 & 2 & 3 & 1 & 2 & 4 & 5 \\
\hline \multicolumn{19}{|c|}{ FLT3 status at relapse } \\
\hline 1 & 2 & 3 & 4 & 5 & 1 & 2 & 3 & 4 & 2 & 3 & 4 & 3 & 4 & 4 & 0 & 0 & 2 & 2 \\
\hline \multicolumn{19}{|c|}{ Patients } \\
\hline - & 6 & 2 & 3 & 1 & 1 & 1 & 1 & 1 & 1 & 3 & 5 & 9 & 5 & 3 & 3 & 1 & 1 & 1 \\
\hline \multicolumn{5}{|c|}{$\begin{array}{l}\text { Total patients } \\
\quad \text { constant: } \mathrm{n}=12\end{array}$} & \multicolumn{10}{|c|}{ progression: $\mathrm{n}=30$} & \multicolumn{4}{|c|}{ regression: $n=6$} \\
\hline
\end{tabular}

Table 5. Karyotype in paired samples at presentation and at relapses in patients with FLT3-LM

\begin{tabular}{lllr}
\hline & Diagnosis & Relapse & Total $(\mathrm{n}=44)$ \\
\hline Constant $(\mathrm{n}=26)$ & $\begin{array}{l}\text { normal karyotype } \\
\text { aberrant karyotype }\end{array}$ & $\begin{array}{l}\text { normal karyotype } \\
\text { same aberrant karyotype }\end{array}$ & 23 \\
\hline Progression $(\mathrm{n}=9)$ & normal karyotype & aberrant karyotype & 4 \\
& aberrant karyotype & same aberrant karyotype with additional aberrations & 4 \\
\hline Regression $(\mathrm{n}=6)$ & aberrant karyotype & normal karyotype & 3 \\
& aberrant karyotype & less aberrant karyotype & 3 \\
\hline Change $(\mathrm{n}=3)$ & aberrant karyotyp & regression + progression & 3 \\
\hline
\end{tabular}

\section{Comparison of FLT3 Status and Karyotype}

Karyotype at diagnosis and relapse was available in 44 paired samples. Most of the cases $(n=23)$ had a normal karyotype at both time points and 4 cases had equal aberrant karyotypes of the prognostically intermediate karyotype group. Thus $27 / 44$ cases $(61.4 \%)$ had stable karyotypes. However, of these 27 cases with stable karyotype 18 had a progression of the FLT3-LM. Five cases with normal karyotype had a chromosomal aberration at relapse. In addition, 5 cases with aberrations had additional aberrations at relapse. All these aberrations were of the prognostically intermediate group as is characteristic for cases with FLT3-LM; thus there was no change with regard to the cytogenetically defined risk group but only gains of a so-called additional chromosomal aberration in the sense of progression. Five of the 10 cases with karyotype progression in parallel showed progression of the FLT3 status. In 6 cases a karyotype regression was detected, 3 of these had a regression and a progression in combination. One (ID 43) also revealed regression of FLT3-LM; however, 5 of these cases revealed a progression of the FLT3LM. Thus cytogenetic regression can be replaced by a molecular progression. Four cases (ID 5, 30, 46, 47) had both a cytogenetic as well as a molecular regression.

\section{Evaluation of FLT3-LM as Follow-Up Marker Using Conventional PCR}

The sensitivity as estimated by the limited dilution series of FLT3-LM-positive patients' RNA or DNA from the time of diagnosis in samples negative for the mutation was dependent on the strength of the initial mutation status and was between 1:100 and 1:1,000 (fig. 2). The course of the disease could be followed according to the wildtype/mutation ratio of the amplification product.

In total 174 bone marrow samples of 45 patients were analyzed during or after therapy. The median sample number per patient was 4 and the median follow-up time of sampling was 12 months.

In 6 cases it was possible to detect FLT3-LM positivity after previous PCR negativity 1-3 months before cytomorphological relapse. In additional 4 cases a pending relapse was detectable due to persistent PCR positivity of the FLT3-LM (examples are depicted in fig. 3). 

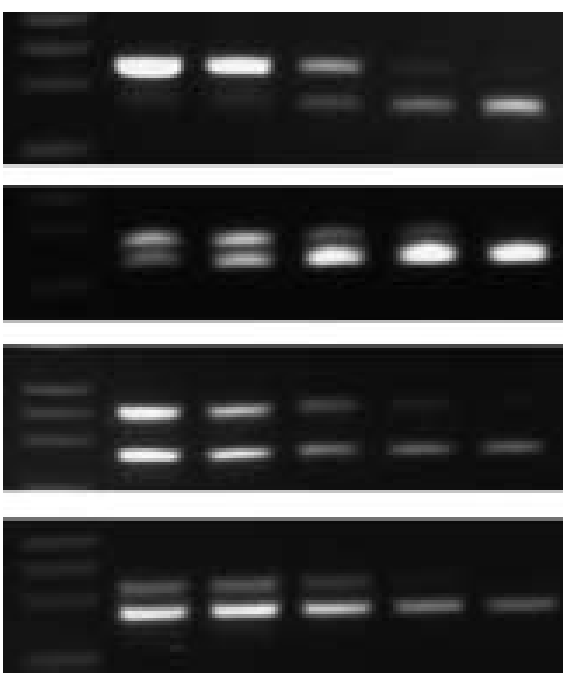

- 음 음 윰 융

\section{FISH and PCR}

In some cases it was possible to perform FISH analysis or PCR using a second marker in parallel to FLT3-LM PCR. For 11 patients with chromosome aberrations at diagnosis a FISH marker was available for follow-up. Four patients with reciprocal translocations could be analyzed with respective colocalization probes [AML1-ETO $(\mathrm{n}=2)$, PML-RARA and CBFB-MYH11]. Four cases had a trisomy 8 that was followed by a centromere 8 probe. One had a $5 \mathrm{q}$ - and 2 a $7 \mathrm{q}$ - that were analyzed with probes from the respective deletion region. In the 4 cases with AML1-ETO, PML-RARA, and CBFB-MYH11 fusion

Fig. 2. Limited dilution assays of FLT-LM-positive DNA of patients with different status at diagnosis into FLT3-LM-negative DNA showing the detection limits of FLT3-LM by conventional PCR.

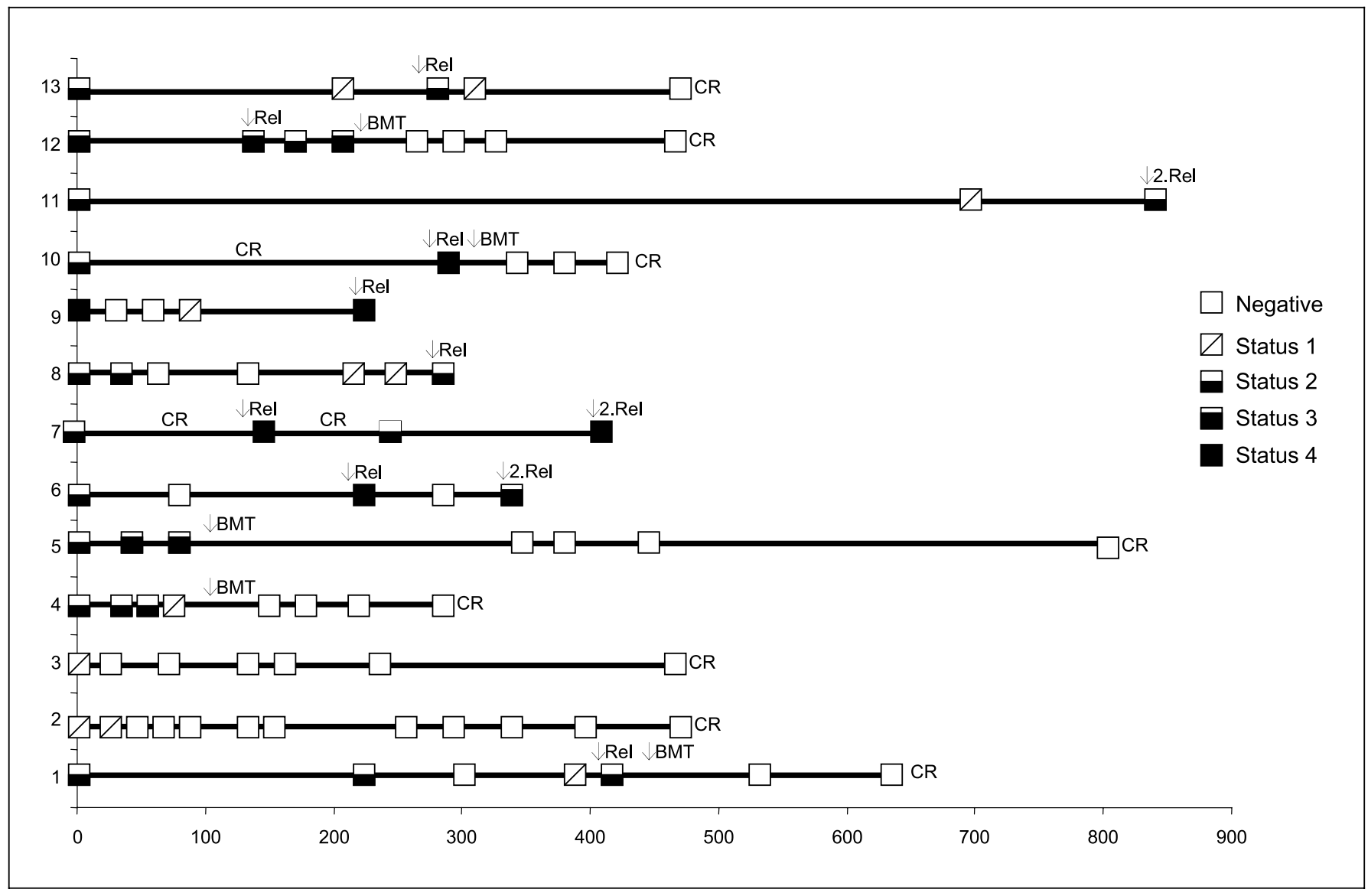

Fig. 3. Follow-up analyses in some exemplary patients showing the possibility of controlling therapy response and of detecting relapses early. $\mathrm{Rel}=$ Relapse; $\mathrm{CR}=$ complete remission; $\mathrm{BMT}=$ bone marrow transplantation . 
gene-specific PCR and FISH were done in parallel to FLT3-PCR. In each of these cases fusion gene-specific PCR was the most sensitive method. In 6 cases $(1 \times$ AML1-ETO, $1 \times$ PML-RARA, $2 \times+8,1 \times 7 q-, 1 \times 5 q-)$ FISH and FLT3 revealed comparable results during follow-up. One case with AML1-ETO and the one with CBFB-MYH11 and low FLT3-LM at diagnosis lost their FLT3-LM at relapse. Two of the cases with trisomy 8,1 with $7 \mathrm{q}$ - and the 1 with $5 \mathrm{q}$-, lost these chromosomal aberrations at relapse but retained the FLT3-LM or even revealed a progression of the FLT3-LM. Thus, for patients with fusion genes, fusion gene-specific PCR or even FISH clearly are superior to FLT3-PCR. However, in cases with other aberrations like trisomy $8,5 \mathrm{q}-$ or $7 \mathrm{q}-$ FLT3-LM PCR seems to be the more reliable follow-up marker.

\section{Discussion}

FLT3-LM is the most frequent genetic marker in AML. It is most commonly found in the intermediate risk group, a subgroup of AML where PCR markers for followup controls have been missing so far. Therefore, it was suggested that an FLT3-LM should be used as a follow-up marker [8]. However, many studies reported on the instability of this marker during the course of the disease [4245]. Here we performed a comprehensive analysis regarding the applicability of the FLT3-LM as a follow-up marker.

We and others have previously shown that the amount of FLT3-LM in comparison to the wild-type allele is heterogeneous $[7,8]$. In the present study in $17 \%$ of the patients at diagnosis and in $84 \%$ at relapse partial or complete loss of the wild-type allele was found. Although the clinical significance of FLT3-LM per se is still discussed controversely the loss of the wild-type allele was reported to be clearly associated with a worse outcome [7, 46]. These patients have a higher white blood cell count, a higher percentage of bone marrow blasts, and a shorter overall and disease-free survival $[7,16,46]$. The loss of WT-FLT3 is of interest with respect to functional aspects. As a mutant FLT3 in a mutant/wild-type heterodimer can trans-phosphorylate the wild-type chain [47]; it implies that a mutant homodimer has some gain of function more than simply activating the kinase. Alternatively, formation of the homodimer may reflect an underlying mechanism of genetic instability that has other unknown genomic consequences that may, in turn, influence clinical outcome.
Different incidences of the patients with loss of the wild type were described in different studies. Whereas Whitman et al. [46] found in $8 / 23(35 \%)$ of their patients a level of mutant greater than the wild-type allele (WT), Fröhling et al. [17] found it in only 1/71 (1.4\%). To some extent, this may reflect differences in the cut-off value for loss of wt allele and stresses the need for a truly quantitative assessment of the FLT3 mutation status even at diagnosis. We found a higher FLT3-LM ratio in comparison to the wt in $11 \%$ at diagnosis, in $32 \%$ at relapse, and complete loss of the WT-FLT3 in 6\% at diagnosis and 52\% at relapse. Thus a loss of the WT-FLT3 is not only associated with a worse prognosis but, in addition, accumulates during the course of the disease and thus seems to be a marker for more progressed disease.

Several studies have been published investigating FLT3 mutations in paired presentation and relapse samples [8, 42-44, 48]. In some of these studies $7-15 \%$ of all AML revealed a gain of the FLT3-LM at relapse [43, 44]. Like in the study presented many of the patients lost their wt at relapse. This accumulation of the FLT3-LM implies a role of FLT3-LM in leukaemia progression and onset of relapse.

Taking the results of these previous studies together with those of the study presented only $88 \%$ of the analyzed patients maintained the same FLT3 status (FLT3LM positive or negative) at both time points. Consequently, as was suggested previously [45] the FLT3-LM should be regarded with caution with respect to its usefulness as a follow-up marker. Patients that were positive for an FLT3-LM at presentation often showed an increased mutant level at relapse, usually with evidence of the loss of wild-type alleles. Where more than one mutation had been detected at presentation, usually only one was dominant at relapse $[8,43,44]$. Thus accumulation in the sense of progression seems to be the most common direction of the instability of the FLT3-LM and does not interfere with the applicability for MRD diagnostics. However, in some studies a significant proportion of patients either gained $(8.3 \%)$ or lost (4\%) an FLT3-LM at relapse, and some patients have been reported with a loss of the presentation LM and a gain of a completely new one at relapse [42-44]. These data imply that FLT3-LM are secondary events, arising in an already transformed clone, which induce the outgrowth of a subclone as a result of an additional proliferative advantage conferred by the FLT3-LM. Further support for the secondary etiology of the FLT3-LM is given by those cases that carry the FLT3LM in only a subset of their leukaemic cells (status 1 mutation in the study presented). In our study all cases 
with a loss of the FLT3-LM at relapse revealed only a low FLT3-LM/wt ratio at diagnosis. One of the cases had a $\mathrm{t}(8 ; 21)$ and one an inv(16) which are subtypes with a rare incidence of FLT3-LM. Also in these cases there seems to be only an FLT3-LM-positive subclone at diagnosis which got lost at relapse. Also these cases had cytogenetically normal clones at diagnosis and not at relapse. Thus in cases with only a low mutation ratio at diagnosis the results of the follow-up analysis should be regarded with special care.

Detailed cytomorphological, cytogenetic, and immunophenotypic analysis of our cases with a loss of the FLT3-LM at relapse revealed a shift of the FAB type and immunophenotype in 2 cases and a complete change of the karyotype in another 2 cases, suggesting that these AML might be secondary AML instead of relapses. Taking together our data and data published in the literature (table 2), only 4\% have a loss of the FLT3-LM. This would be the subgroup that would escape early detection of relapse. However, from our experience this is in the same range as other leukaemias (for example, those followed up with AML1-ETO or CBFB-MYH11) 'relapse' with a different AML. In all of these cases an impending relapse cannot be detected with molecular methods. In addition, therapy response in the early course of the disease can also be applied in these $4 \%$ of cases.

For individual patients it was possible to apply different methods of follow-up controls in parallel. It was shown that in patients with fusion genes, fusion gene-specific PCR was clearly superior to FLT3-PCR because it is quantitative instead of semiquantitative and more sensitive. Even the fusion gene-specific FISH analysis was more sensitive in these cases, because all these cases had a very low FLT3-LM status at diagnosis. In contrast, in cases with other aberrations like trisomy $8,5 \mathrm{q}-$ or $7 \mathrm{q}-$ FLT3-LM was more reliable than FISH specific for the respective chromosome aberrations, because all these chromosome aberrations were unstable at relapse and FLT3-PCR although being not highly sensitive with a sensitivity of 1:1,000 is more sensitive than FISH.

To make the FLT3-LM assessment truly semiquantitative, we suggest that GeneScan analysis should be used at diagnosis for better prognostication [7]. During follow-up this method would also improve the estimation of the reduction of the leukemic cells in comparison to standard PCR and gel electrophoresis. It could be shown that realtime quantification with patient-specific primers for individual FLT3-LM is applicable and highly specific and sensitive. Thus in the future a highly sensitive and quantitative PCR may still improve the use of FLT3-LM as a follow-up marker. However, this approach is time consuming and expensive and for prospective assessment of the FLT3-LM in clinical studies it does not seem to be feasible for most of the diagnostic labs.

As FLT3-LM characterizes an unfavourable subset of the intermediate group with an increased risk for relapse it is of high importance to monitor especially this group. With the present study it could be shown that FLT3-LM indeed is a reliable marker to assess therapy response and it was even possible to detect relapse early up to 3 months before a clinical relapse. In 94\% of cases with FLT3-LM at diagnosis it is also present at relapse. However, the amount of the mutation in relation to the wild-type allele is increasing in $63 \%$ of the cases. It seems to be a common signature of the FLT-LM that the status is increasing in the course of unfavourable disease.

Although the applicability of FLT3-LM as marker for follow-up controls was regarded quite critically [43, 45] the results of the presented study are encouraging. This study using conventional qualitative PCR shows that FLT3 is a reliable marker for follow-up controls in most of the patients carrying an FLT3-LM at diagnosis.

\section{References}

1 Matthews W, Jordan CT, Wiegand GW, Pardoll D, Lemischka IR: A receptor tyrosine kinase specific to hematopoietic stem and progenitor cell-enriched populations. Cell 1991; 65:1143-1152.

2 Lyman SD, Jacobsen SE: c-kit ligand and Flt3 ligand: Stem/progenitor cell factors with overlapping yet distinct activities. Blood 1998;91: $1101-1134$
3 Kiyoi H, Naoe T, Nakano Y, Yokota S, Minami S, Miyawaki S, Asou N, Kuriyama K, Jinnai I, Shimazaki C, Akiyama H, Saito K, Oh H, Motoji T, Omoto E, Saito H, Ohno R, Ueda R: Prognostic implication of FLT3 and N-RAS gene mutations in acute myeloid leukemia. Blood 1999;93:3074-3080.

4 Abu-Duhier FM, Goodeve AC, Wilson GA, Gari MA, Peake IR, Rees DC, Vandenberghe EA, Winship PR, Reilly JT: FLT3 internal tandem duplication mutations in adult acute myeloid leukaemia define a high-risk group. $\mathrm{Br} \mathrm{J}$ Haematol 2000;111/1:190-195.
5 Meshinchi S, Woods WG, Stirewalt DL, Sweester DA, Buckley JD, Tjoa TK, Bernstein ID, Radich JP: Prevalence and prognostic significance of FLT3 internal tandem duplication in pediatric acute myeloid leukemia. Blood 2001; 97:89-94.

6 Rombouts WJ, Martens AC, Ploemacher RE: Identification of variables determining the engraftment potential of human acute myeloid leukemia in the immunodeficient NOD/SCID human chimera model. Leukemia 2000;14: 889-897. 
7 Thiede C, Steudel C, Mohr B, Schaich M, Schakel U, Platzbecker U, Wermke M, Bornhauser M, Ritter M, Neubauer A, Ehninger G, Illmer $\mathrm{T}$ : Analysis of FLT3-activating mutations in 979 patients with acute myelogenous leukemia: Association with FAB subtypes and identification of subgroups with poor prognosis. Blood 2002;99:4326-4335.

8 Schnittger S, Schoch C, Dugas M, Kern W, Staib P, Wuchter C, Löffler H, Sauerland CM, Serve H, Büchner T, Haferlach T, Hiddemann W: Analysis of FLT3 length mutations in 1003 patients with acute myeloid leukemia: Correlation to cytogenetics, FAB subtype, and prognosis in the AMLCG study and usefulness as a marker for the detection of minimal residual disease. Blood 2002;100/1:59-66.

9 Abu-Duhier FM, Goodeve AC, Wilson GA, Care RS, Peake IR, Reilly JT: Identification of novel FLT-3 Asp835 mutations in adult acute myeloid leukaemia. Br J Haematol 2001;113: 983-988.

10 Yamamoto Y, Kiyoi H, Nakano Y, Suzuki R, Kodera Y, Miyawaki S, Asou N, Kuriyama K, Yagasaki F, Shimazaki C, Akiyama H, Saito K, Nishimura M, Motoji T, Shinagawa K, Takeshita A, Saito H, Ueda R, Ohno R, Naoe T Activating mutation of D835 within the activation loop of FLT3 in human hematologic malignancies. Blood 2001;97:2434-2439.

11 Schnittger S, Böll I, Schoch C, Dugas M, Kern W, Sauerland CM: FLT3D835/I836 point mutations in acute myeloid leukemia: Correlation to cytogenetics, cytomorphology and prognosis in 1229 patients. Blood 2002;100(suppl):abstract 735 .

12 Kiyoi H, Towatari M, Yokota S, Hamaguchi M, Ohno R, Saito H, Naoe T: Internal tandem duplication of the FLT3 gene is a novel modality of elongation mutation which causes constitutive activation of the product. Leukemia 1998;12:1333-1337.

13 Mizuki M, Fenski R, Halfter H, Matsumura I, Schmidt R, Muller C, Gruning W, KratzAlbers K, Serve S, Steur C, Büchner T, Kienast J, Kanakura Y, Berdel WE, Serve H: Flt3 mutations from patients with acute myeloid leukemia induce transformation of $32 \mathrm{D}$ cells mediated by the Ras and STAT5 pathways. Blood 2000;96:3907-3914.

14 Hayakawa F, Towatari M, Kiyoi H, Tanimoto M, Kitamura T, Saito H, Naoe T: Tandemduplicated Flt3 constitutively activates STAT5 and MAP kinase and introduces autonomous cell growth in IL-3-dependent cell lines. Oncogene 2000;19:624-631.

15 Yokota S, Kiyoi H, Nakao M, Iwai T, Misawa S, Okuda T, Sonoda Y, Abe T, Kahsima K, Matsuo Y, Naoe T: Internal tandem duplication of the FLT3 gene is preferentially seen in acute myeloid leukemia and myelodysplastic syndrome among various hematological malignancies. A study on a large series of patients and cell lines. Leukemia 1997;11:1605-1609.
16 Kottaridis PD, Gale RE, Frew ME, Harrison $\mathrm{G}$, Langabeer SE, Belton AA, Walker $\mathrm{H}$, Wheatley K, Bowen DT, Burnett AK, Goldstone AH, Linch DC: The presence of a FLT3 internal tandem duplication in patients with acute myeloid leukemia (AML) adds important prognostic information to cytogenetic risk group and response to the first cycle of chemotherapy: Analysis of 854 patients from the United Kingdom Medical Research Council AML 10 and 12 trials. Blood 2001;98:17521759.

17 Fröhling S, Schlenk RF, Breitruck J, Benner A, Kreitmeier S, Tobis K, Döhner H, Döhner K: Prognostic significance of activating FLT3 mutations in younger adults (16 to 60 years) with acute myeloid leukemia and normal cytogenetics: A study of the AML Study Group Ulm. Blood 2002;100:4372-4380.

18 Schoch C, Haferlach T: Cytogenetics in acute myeloid leukemia. Curr Oncol Rep 2002;4: 390-397.

19 Grimwade D, Walker H, Oliver F, Wheatley K, Harrison C, Harrison G, Rees J, Hann I, Stevens RF, Burnett AK, Goldstone AH, on behalf of the Medical Research Council Adult and Children's Leukemia Working Parties: The importance of diagnostic cytogenetics on outcome in AML: Analysis of 1,612 patients entered into the MRC AML 10 trial. Blood 1998;92: 2322-2333.

20 Kern W, Haferlach T, Schoch C, Loeffler H, Gassmann W, Heinecke A, Sauerland MC, Berdel W, Buechner T, Hiddemann W: Early blast clearance by remission induction therapy is a major independent prognostic factor for both achievement of complete remission and long-term outcome in acute myeloid leukemia: Data from the German AML Cooperative Group 1992 Trial. Blood 2003;101:64-70.

21 Estey EH, Shen Y, Thall PF: Effect of time to complete remission on subsequent survival and disease-free survival time in AML, RAEB-t, and RAEB. Blood 2000;95/1:72-77.

22 Wheatley K, Burnett AK, Goldstone AH, Gray RG, Hann IM, Harrison CJ, Rees JK, Stevens RF, Walker H: A simple, robust, validated and highly predictive index for the determination of risk-directed therapy in acute myeloid leukaemia derived from the MRC AML 10 trial. United Kingdom Medical Research Council's Adult and Childhood Leukaemia Working Parties. Br J Haematol 1999;107/1:69-79.

23 Kern W, Schnittger S: Monitoring of acute myeloid leukemia by flow cytometry. Curr Oncol Rep 2003;5:405-412.

24 Cassinat B, Zassadowski F, Balitrand N, Barbey C, Rain JD, Fenaux P, Degos L, Vidaud M, Chomienne C: Quantitation of minimal residual disease in acute promyelocytic leukemia patients with $\mathrm{t}(15 ; 17)$ translocation using realtime RT-PCR. Leukemia 2000;14:324-328.

25 Wattjes MP, Krauter J, Nagel S, Heidenreich O, Ganser A, Heil G: Comparison of nested competitive RT-PCR and real-time RT-PCR for the detection and quantification of AML1/ MTG8 fusion transcripts in $\mathrm{t}(8 ; 21)$ positive acute myelogenous leukemia. Leukemia 2000; 14:329-335.
26 Krauter J, Wattjes MP, Nagel S, Heidenreich O, Krug U, Kafert S, Bunjes D, Bergmann L, Ganser A, Heil G: Real-time RT-PCR for the detection and quantification of AML1/MTG8 fusion transcripts in $\mathrm{t}(8 ; 21)$-positive AML patients. Br J Haematol 1999;107/1:80-85.

27 Krauter J, Hoellge W, Wattjes MP, Nagel S, Heidenreich O, Bunjes D, Ganser A, Heil G: Detection and quantification of $\mathrm{CBFB} /$ MYH11 fusion transcripts in patients with inv(16)-positive acute myeloblastic leukemia by real-time RT-PCR. Genes Chromosomes Cancer 2001;30:342-348.

28 Marcucci G, Caligiuri MA, Döhner H, Archer KJ, Schlenk RF, Döhner K, Maghraby EA, Bloomfield CD: Quantification of CBFbeta/ MYH11 fusion transcript by real time RTPCR in patients with INV(16) acute myeloid leukemia. Leukemia 2001;15:1072-1080.

29 Buonamici S, Ottaviani E, Testoni N, Montefusco V, Visani G, Bonifazi F, Amabile M, Terragna $\mathrm{C}$, Ruggeri $\mathrm{D}$, Piccaluga $\mathrm{PP}$, Isidori $\mathrm{A}$, Malagola M, Baccarani M, Tura S, Martinelli G: Real-time quantitation of minimal residual disease in inv(16)-positive acute myeloid leukemia may indicate risk for clinical relapse and may identify patients in a curable state. Blood 2002;99:443-449.

30 Guerrasio A, Pilatrino C, De Micheli D, Cilloni D, Serra A, Gottardi E, Parziale A, Marmont F, Diverio D, Divona M, Lo CF, Saglio G: Assessment of minimal residual disease (MRD) in CBFbeta/MYH11-positive acute myeloid leukemias by qualitative and quantitative RTPCR amplification of fusion transcripts. Leukemia 2002;16:1176-1181.

31 Gallagher RE, Yeap BY, Bi W, Livak KJ, Beaubier N, Rao S, Bloomfield CD, Appelbaum FR, Tallman MS, Slack JL, Willman CL: Quantitative real-time RT-PCR analysis of PML-RAR alpha mRNA in acute promyelocytic leukemia: Assessment of prognostic significance in adult patients from intergroup protocol 0129. Blood 2003;101:2521-2528.

32 Schnittger S, Weisser M, Schoch C, Hiddemann W, Haferlach T, Kern W: New score predicting for prognosis in PML-RARA-, AML1ETO-, or CBFB-MYH11-positive acute myeloid leukemia based on quantification of fusion transcripts. Blood 2003;102:2746-2755.

33 Bennett JM, Catovsky D, Daniel MT, Flandrin G, Galton DA, Gralnick HR, Sultan C: Proposals for the classification of the myelodysplastic syndromes. Br J Haematol 1982;51:189-199.

34 Bennett JM, Catovsky D, Daniel MT, Flandrin G, Galton DA, Gralnick HR, Sultan C: Proposals for the classification of the acute leukaemias. French-American-British (FAB) co-operative group. Br J Haematol 1976;33:451-458.

35 Bennett JM, Catovsky D, Daniel MT, Flandrin G, Galton DA, Gralnick HR, Sultan C: Proposal for the recognition of minimally differentiated acute myeloid leukaemia (AML-MO). Br J Haematol 1991;78:325-329.

36 Bennett JM, Catovsky D, Daniel MT, Flandrin G, Galton DA, Gralnick HR, Sultan C: A variant form of hypergranular promyelocytic leukaemia (M3). Br J Haematol 1980;44/1:169_ 170 . 
37 Bennett JM, Catovsky D, Daniel M-T, Flandrin G, Galton DAG, Gralnick HR, Sultan C: Criteria for the diagnosis of acute leukemia of megakaryocyte lineage (M7). Ann Intern Med 1985;103:406-462.

38 Bennett JM, Catovsky D, Daniel MT, Flandrin G, Galton DA, Gralnick HR, Willman CL: Hypergranular promyelocytic leukemia: Correlation between morphology and chromosomal translocations including $\mathrm{t}(15 ; 17)$ and $\mathrm{t}(11 ; 17)$. Leukemia 2000;14:1197-1200.

39 Schoch C, Schnittger S, Bursch S, Gerstner D, Hochhaus A, Berger U, Hehlmann R, Hiddemann W, Haferlach T: Comparison of chromosome banding analysis, interphase- and hypermetaphase-FISH, qualitative and quantitative PCR for diagnosis and for follow-up in chronic myeloid leukemia: A study on 350 cases. Leukemia 2002;16/1:53-59.

40 Mitelman F: ISCN: Guidelines for Cancer Cytogenetics. Supplement to an International System for Human Cytogenetic Nomenclature. Basel, Karger, 1995

41 Miller SA: A simple salting out procedure for extracting DNA from human nucleated cells. Nucleic Acids Res 1988;16:1215-1216.
42 Hovland R, Gjertsen BT, Bruserud O: Acute myelogenous leukemia with internal tandem duplication of the Flt3 gene appearing or altering at the time of relapse: A report of two cases. Leuk Lymphoma 2002;43:2027-2029.

43 Kottaridis PD, Gale RE, Langabeer SE, Frew ME, Bowen DT, Linch DC: Studies of FLT3 mutations in paired presentation and relapse samples from patients with acute myeloid leukemia: Implications for the role of FLT3 mutations in leukemogenesis, minimal residual disease detection, and possible therapy with FLT3 inhibitors. Blood 2002;100:2393-2398.

44 Shih LY, Huang CF, Wu JH, Lin TL, Dunn P, Wang PN, Kuo MC, Lai CL, Hsu HC: Internal tandem duplication of FLT3 in relapsed acute myeloid leukemia: A comparative analysis of bone marrow samples from 108 adult patients at diagnosis and relapse. Blood 2002;100: 2387-2392.

45 Gilliland DG: Murky waters for MRD detection in AML: Flighty FLT3/ITDs. Blood 2002; 100:2277B.

46 Whitman SP, Archer KJ, Feng L, Baldus C, Becknell B, Carlson BD, Carroll AJ, Mrozek K, Vardiman JW, George SL, Kolitz JE, Larson RA, Bloomfield CD, Caligiuri MA: Absence of the wild-type allele predicts poor prognosis in adult de novo acute myeloid leukemia with normal cytogenetics and the internal tandem duplication of FLT3:A cancer and leukemia group B study. Cancer Res 2001;61:72337239 .
47 Kottaridis PD, Gale RE, Linch DC: Flt3 mutations and leukaemia. Br J Haematol 2003;122: 523-538.

48 Nakano Y, Kiyoi H, Miyawaki S, Asou N, Ohno R, Saito H, Naoe T: Molecular evolution of acute myeloid leukaemia in relapse: Unstable N-ras and FLT3 genes compared with p53 gene. Br J Haematol 1999; 104:659-664.

49 Schnittger S, Schoch C, Kern W, Haferlach T, Hiddemann W: FLT3-LM and MLL-PTD as markers for PCR-based detection of minimal residual disease (MRD) in AML with normal karyotype. Blood 2001;98:581A

50 Hovland R, Gjertsen BT, Bruserud O: Acute myelogenous leukemia with internal tandem duplication of the Flt3 gene appearing or altering at the time of relapse: a report of two cases. Leuk Lymphoma 2002;43:2027-2029.

51 Stirewalt DL, Willman CL, Radich JP: Quantitative, realt-ime polymerase chain reactions for FLT3 internal tandem duplications are highly sensitive and specific. Leuk Res 2001;25:10851088 . 